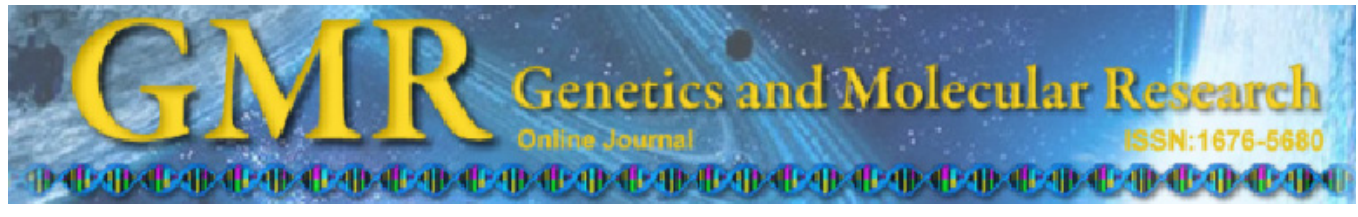

\title{
Genetic and environmental effects on age at first farrowing in sows in southeastern Brazil
}

\author{
A. Cavalcante-Neto ${ }^{1}$, J.F. Lui' ${ }^{2}$, J.L.R. Sarmento ${ }^{3}$, M.N. Ribeiro ${ }^{4}$, \\ C. Fonseca ${ }^{1}$, H. Tonhati ${ }^{2}$, J.M.C. Monteiro ${ }^{5}$, M.A.C. Lara ${ }^{6}$ and \\ S.A. Queiroz ${ }^{2}$
}

${ }^{1}$ Departamento de Biologia \& CESAM, Universidade de Aveiro, Aveiro, Portugal

${ }^{2}$ Departamento de Zootecnia, Universidade Estadual Paulista "Julio de Mesquita Filho", Jaboticabal, SP, Brasil ${ }^{3}$ Universidade Federal do Piauí, Bom Jesus, PI, Brasil ${ }^{4}$ Universidade Federal Rural de Pernambuco, Recife, PE, Brasil ${ }^{5}$ Escola Técnica Federal de Muzambinho, Muzambinho, MG, Brasil ${ }^{6}$ Instituto de Zootecnia, Nova Odessa, SP, Brasil

Corresponding author: A. Cavalcante-Neto E-mail: aderbalcavalcante@gmail.com

Genet. Mol. Res. 10 (4): 2860-2866 (2011)

Received April 11, 2011

Accepted September 12, 2011

Published October 31, 2011

DOI http://dx.doi.org/10.4238/2011.October.31.9

\begin{abstract}
We evaluated genetic and environmental factors affecting age at first farrowing of sows in the Brazilian southeast. For this purpose, 466 observations regarding the age at first farrowing were made for Dalland- $\mathrm{C} 40^{\circ}$ animals belonging to two herds. The effects of the environmental factors on this trait were assessed by means of a model that included, as random effects, the influence of the sow's father and mother and, as fixed effects, the influence the year of birth, the herd and the birth season, along with the covariable litter size at birth. The variance components were estimated using the derivative-free restricted maximum likelihood method. The estimated mean was $354.8 \pm 25.87$ days, with a coefficient of variation of $7.29 \%$. Significant effects on the trait were observed for the herd, the year and the season of birth;
\end{abstract}


but a linear effect of litter size at birth on the age at first farrowing was not observed. The boar did not significantly contribute to the variation occurring among the sows, whereas the sow's mother caused significant variation. The heritability estimate for the age at first farrowing was $0.44 \pm 0.15$, which is considered high. We concluded that herd effect and year and season of birth should be taken into consideration for an accurate genetic comparison; consequently, the animals should be joined into contemporary groups.

Key words: Puberty; Reproduction; Non-genetic factors

\section{INTRODUCTION}

Animal breeding companies have been attempting to improve the female lineages used in crossing to produce $\mathrm{F}_{1}$ female, as it has been proven that this is the most productive of all possible crossing, not only because of the great number of live-born piglets per farrowing but also because of their good feed intake in the maternity period, and consequently weaning in good body condition. Sows that are with good body shape at weaning of their litter have an interval between weaning and the following estrus that is beneficial to the farrowing rate of the herd, as is the number of farrowings of each sow and, consequently, the number of weaned piglets per sow per year (Antunes, 2002; Gomes da Silva et al., 2007; Cavalcante-Neto et al., 2011).

Environmental and genetic factors can influence the reproductive and productive trait of pigs (Silveira et al., 2009; Cesar et al., 2010; Médici et al., 2010). Knowledge of the influence of environmental and genetic factors on these traits is becoming increasingly important (Cavalcante-Neto et al., 2009a; Leite et al., 2011), considering the geographic dimensions of Brazil, with regions of different climates, not to mention deficient management, inadequate facilities, and animals that are not always of high breeding value (Pinheiro et al., 2000; Cavalcante-Neto et al., 2008a, 2009b).

Studies showing the influence of genetic and non-genetic factors on the age at first farrowing in pigs from Brazil are still scarce in the literature. Therefore further research on that matter is necessary, considering its great economic importance in a production system. This study was aimed at evaluating the genetic and non-genetic factors which affect the age at first farrowing of sows from southeastern Brazil.

\section{MATERIAL AND METHODS}

For this research, 466 records regarding the age at first farrowing of Dalland-C40 ${ }^{\circ}$ sows were used. The animals belonged to Granja São José - Irmãos Canalli (herd 1), located in the municipality of Monte Alto, SP, and to Suinocultura São José (herd 2), located in the municipality of Cabo Verde, MG.

The city of Monte Alto, SP, has annual rainfall of around $1552.1 \mathrm{~mm}$. The relative humidity is approximately $21.4 \%$, with a hot climate and dry winter. Its mean annual temperature is approximately $22^{\circ} \mathrm{C}$, with predominantly southerly winds (Prefeitura Municipal de Monte Alto, 2006). The city of Cabo Verde, MG, has annual rainfall of around $1605.2 \mathrm{~mm}$, a hot climate and dry winter. Its mean annual temperature is approximately $18.2^{\circ} \mathrm{C}$, and its altitude 
is $780 \mathrm{~m}$ (Bússola Net, 2006).

The animals were all penned in a conventional brick building coated with cement and a watertight floor, with pickets in the units designed for mating. The feed provided to the breeding stock was of a commercial type, meeting the nutritional requirements of all raising phases.

The birth seasons of the animals were grouped into four trimesters: 1 - January through March; 2 - April through June; 3 - July through September; 4 - October through December.

To obtain more consistent data, some restrictions were made, thus considering for the analysis only information from reproducers with at least three daughters. It was also defined that the contemporary groups should include at least four observations. Once these restrictions were made, 466 records of age at first farrowing of sows that were the daughters of 15 boars and 120 dams were left.

The Statistical Analysis System (SAS, 1999) was used for the formation of files, consistency and descriptive analysis of the data, as well as for the assessment of the effects of environmental factors on the trait, for which the GLM procedure was used, considering the RANDOM option that treats the effect of the reproducer as random, by means of the following model:

$$
\mathrm{Y}_{\mathrm{ijklm}}=\mu+\mathrm{C}_{\mathrm{i}}+\mathrm{M}_{\mathrm{j}}+\mathrm{A}_{\mathrm{k}}+\mathrm{E}_{1}+\mathrm{R}_{\mathrm{m}}+\mathrm{b}_{1}\left(\mathrm{I}_{\mathrm{ijk} k \mathrm{~m}}-\mathrm{I}\right)+\mathrm{e}_{\mathrm{ijklmn}}
$$

where $Y_{i j k l m}=$ age at first farrowing of the sow whose parents are boar $i$ and dam $j$, in year $k$, season $l$, in herd $m ; \mu=$ general mean; $C_{i}=$ random effect of the $\mathrm{i}^{\text {th }}$ boar that is the sow's father nested herd; $M_{j}=$ random effect of the $\mathrm{i}^{\text {th }}$ dam that is the sow's mother nested herd; $A_{k}=$ fixed effect of the $\mathrm{k}^{\text {th }}$ year of birth; $E_{l}=$ fixed effect of the $1^{\text {th }}$ season of birth; $R_{m}=$ fixed effect of the $\mathrm{m}^{\text {th }}$ herd of birth; $b_{1}=$ linear regression coefficient of the trait in relation to the total size of the first litter at birth; $I_{i j k l m}=$ litter size at first farrowing; $I=$ mean of litter size at first farrowing, and $e_{i j k l m n}=$ random error associated with each observation, with $\mu=0$ and variance $=\delta^{2}$.

By studying the variables included in the models, it is possible to assess the isolated and combined contributions of each one of them and to determine a simpler model that fits the studied trait best. In this sense, the effects of all possible interactions between the fixed effects were tested and, whenever they had no statistical significance $(P>0.05)$, they were excluded from the analysis.

The variance components were estimated by the restricted maximum likelihood method free of derivatives, using the MTDFREML software (Boldman et al., 1995) applied to animal models. The adopted model was:

$$
\mathrm{y}=\mathrm{Xb}+\mathrm{Z}_{1} \mathrm{~d}+\mathrm{Z}_{2} \mathrm{c}+\varepsilon
$$

where $y=$ vector of observations; $X=$ incidence matrix of fixed effect; $b=$ vector of fixed effect; $Z_{1}=$ incidence matrix of direct additive genetic effect; $d=$ vector of direct additive genetic effect; $Z_{2}=$ incidence matrix of common litter environmental effect; $c=$ vector of common litter environmental effect, and $\varepsilon=$ vector of residual effect.

It was assumed that vectors $d, c$ and $\varepsilon$ have a normal distribution with $\mathrm{E}(\mathrm{d})=\mathrm{E}(\mathrm{c})=\mathrm{E}(\varepsilon)$ $=0$ and $\operatorname{Var}(\mathrm{d})=A \sigma_{d}^{2} ; \operatorname{Var}(\mathrm{c})=I_{n} \sigma_{c}^{2} ; \operatorname{Var}(\varepsilon)=I_{N} \sigma_{e}^{2}$, where $\sigma_{d}^{2}, \sigma_{c}^{2}$ and $\sigma_{e}^{2}$ are the direct genetic additive, the common litter environmental and the residual variances, respectively; $A$ is the Wright's kinship coefficient matrix between the animals; $I_{n}$ is an identity matrix of order $\mathrm{n}$, where $n$ is the number of litter; $I_{N}$ is an identity matrix of order $\mathrm{N}$, where $N$ is the number of observations. 
The fixed effect considered in the genetic analyses was the group of contemporary, formed by animals born in the same year $(2000, \ldots, 2004)$, same season $(1,2,3$, and 4$)$ and same herd (1 and 2).

The convergence criterion used was a variance of the simplex values ( $-2 \log$ of likelihood) inferior to $10^{-9}$. After each convergence, the program was restarted using the previously obtained estimates as initial values. This procedure was then repeated until the differences between the estimates of the last two convergences were smaller than $10^{-9}$.

\section{RESULTS}

In this study, the estimated mean for the age at first farrowing (AFF) was $354.8 \pm$ 25.87 days, with a coefficient of variation of $7.29 \%$.

Analysis of variance (Table 1) showed that the effects of the year and the season of birth were significant $(\mathrm{P}<0.01)$. Likewise, a significant effect $(\mathrm{P}<0.005)$ was also found between herds. Linear regression of the total number of piglets born in the first litter, in relation to AFF, showed no significance at the $5 \%$ probability level. The effect of the boar $(\mathrm{P}=0.35)$ was not important for the AFF, whereas the sow's mother $(\mathrm{P}=0.01)$ was a major source of variation.

\begin{tabular}{|c|c|c|c|}
\hline Sources of variation & d.f. & Mean square & $\mathrm{P}$ \\
\hline Sow's father nested herd & 14 & 478.35816 & 0.3543 \\
\hline Sow's mother nested herd & 119 & 608.93747 & 0.01 \\
\hline Year of birth & 4 & 3315.69247 & $<0.0001$ \\
\hline Season of birth & 3 & 1733.04806 & 0.0082 \\
\hline Herd & 1 & 5561.28238 & 0.0004 \\
\hline Total of piglets born in the first litter (linear) & 1 & 85.58132 & 0.6572 \\
\hline Residue & 324 & 433.8330 & \\
\hline
\end{tabular}

d.f. $=$ degrees of freedom.

The estimated heritability for the age at first farrowing was $0.44 \pm 0.15$, a magnitude considered high, which indicates that this trait might present a genetic gain in response to selection. The estimated common litter environmental effect was $0.19 \pm 0.07$, representing $19 \%$ of the total phenotypic variation.

\section{DISCUSSION}

A mean value lower than the one found in the present study was reported by Torres Filho et al. (2004), who found a mean of 318.56 days in animals of the Large White breed. This difference may be due to the fact that this study was performed with commercial herds, for which each breeder determines in his own way the best time to have his sows mated. Some producers delay the entry of their sows in reproduction, determining an age or weight for starting their reproductive life, thus making it even more difficult to identify the sexually precocious females. However, the herd used by Torres Filho et al. (2004) originates from a genetic improvement program, which makes it likely that they received better follow-up for this purpose. Roehe and Kennedy (1995), who worked with animals of the Yorkshire and Landrace breeds in Canada, obtained mean values of 365 and 360.5 days, respectively. Bárcena (2003) 
emphasizes that there is a difference between purebred and crossbred sows, both in the ovulation rate and in the age of onset of puberty, the same difference being also observed between white and dark breeds.

Irgang (1977) used reproductive performance data on Large White females, recorded in the Pig Book of the Brazilian Pig Breeders' Association, and found a mean value of 14.11 months (423.3 days) at first farrowing. The author considered at the time that this value was rather high. Based on this statement, on the findings of Torres Filho et al. (2004) and on the results obtained in this study, we suggest that there has been genetic progress and/or environmental improvement regarding this trait in Brazil.

The effects of the year and season of birth demonstrate that the supply of raw material for feed manufacturing in those years was incompatible with commercial pig breeding. Corn shortages and difficulties in obtaining soy bran forced the producers to find substitutes with lower biological value, resulting in a poorer reproductive performance of the animals. According to Giné (2002), many causes can contribute to the influence of the year and the season on pig raising. Among them, changes in management, in feed and in the quality of its ingredients, in the nutritional requirements, and in the climatic environment are worth mentioning. Thus, some adjustments in the feeding management could attenuate the influence of these effects.

The herd effect in turn consists of a set of management practices used on each farm during the growing and development phases of the sows, with the purpose of obtaining gilts which attain a good weight for the first service. Several authors affirm that the differences between herds are a factor that can significantly affect the reproductive traits of sows (Cavalcante-Neto et al., 2008b). According to Irgang et al. (1990), puberty at a younger or older age depends on the season of birth of the sows, on their moving around, involving change of pens, of diet, of the number of gilts per group during the pre-pubertal phase, and on the presence and stimulation of the male.

The evolution of pig breeding programs has resulted in a significant increase in the total litter size per sow. In this context, it has been reported that females with larger litters presented a shorter pregnancy length than those with small litters (Upnmoor, 2000; Mellagi et al., 2005). Based on this observation, the hypothesis has been raised that the total size of the first litter could influence the AFF, since - according to Mellagi et al. (2005) and Upnmoor (2000) - larger litters bring about a shorter gestation length, which would result in a younger age at first farrowing, even by only a few days.

This is, however, a controversial subject: it has also been reported that litter size has little influence on the gestation length (Day, 1980); some authors have found a positive correlation between the gestation length and the litter size at birth (Omtvedt et al., 1965), whereas Mellagi et al. (2005) found a significant $(\mathrm{P}<0.05)$, although low $(-0.19)$, negative correlation between the litter size and the gestation length; there are also those who state that there is no correlation between these factors (Cox, 1964; cited from Omtvedt et al., 1965).

According to First et al. (1982), triggering of the delivery starts with the release of cortisol by the fetuses. This substance stimulates the placenta to convert progesterone into estrogen. These high levels of estrogen stimulate the development of oxytocin receptors and the secretion of PGF $2 \alpha$ by the endometrium, causing luteolysis. Based on this, one could also assume that, the larger the number of cortisol-releasing fetuses, the faster the mother would enter into labor.

The heritability estimate obtained in this study indicates that phenotype is a good indi- 
cator of the individuals' genotype. Thus, it is expected that individual selection in sows would produce satisfactory genetic gains. The heritability value obtained here is higher than the one reported by Torres Filho et al. (2005), who used a model that, in addition to the additive genetic effect, also took into account the maternal genetic and the common litter environmental effects, thus obtaining the heritability value of 0.34 . Our result, however, is closer to that of Irgang (1985), who found an estimated heritability of 0.49 for the female's age at first farrowing. According to Freitas (1998), a reduction of the age at puberty means a younger age at service and first farrowing, reducing the age of the females' entrance into the breeding stock, which in turn represents, from the economic standpoint, a lower litter production cost. The same author also pointed out that this trait has $30 \%$ heritability, as well as genetic and phenotypic correlations, which are favorable to the growth rate, with additive variation and abundant pleiotropic effects for changes in puberty.

In the present study, the common litter environmental effect accounted for $19 \%$ of the total phenotypic variation among the sows, thus demonstrating the importance of including this effect in the genetic analysis models. In this sense, Mrode (1996) pointed out that the inclusion of the common environmental effect in the model increases the accuracy in predicting the breeding values of the animals. Torres Filho et al. (2005) stated that the estimate of the common litter environmental effect for a sow's age at first farrowing highlights the importance of its inclusion in genetic model for this trait, considering that it accounted for $11 \%$ of the total phenotypic variation.

\section{CONCLUSION}

We concluded that, for an accurate genetic comparison, the year and season of birth should be taken into consideration, in addition to the herd effect, and therefore the animals must be joined in contemporary groups. The estimated heritability value for the sow's age at first farrowing indicates that the selection applied on this trait is likely to result in genetic gain.

\section{ACKNOWLEDGMENTS}

We acknowledge the collaboration of the Canalli brothers representing the pig farm São José in Monte Alto, SP, Brazil, and of Mr. Adriano Muniz representing the pig farm São José in Cabo Verde, MG, Brazil, who kindly provided the data that allowed this research to be performed. A. Calvacante-Neto was supported by a grant from Fundação para a Ciência e Tecnologia (FCT-MCT; SFRH/BD/47821/2008) and from the ALBAN Programme, the European Union Programme of High Level Scholarships for Latin America (Scholarship \#E07D402597BR).

\section{REFERENCES}

Antunes RC (2002). Avanços e perspectivas do melhoramento genético de suínos. Porkworld 2: 100-102.

Bárcena MR (2003). Ciclo estral: endocrinologia, detecção, manipulação e sicronização. Porkworld 15: 32-36.

Boldman KG, Kriese LA, Van Vleck DL and Kachman SD (1995). A Manual for use of MTDFREML. A Set of Programs to Obtain Estimates of Variances and Covariances [DRAFT] Lincoln. USDA/ARS, Lincoln.

Bússula Net (2006). Available at [http://www.bussolanet.com.br]. Accessed May 20, 2011.

Cavalcante-Neto A, Lui JF, Sarmento JLR, Monteiro JMC, et al. (2008a). Fatores ambientais e estimativa de herdabilidade para o intervalo desmame-cio em fêmeas suínas. Rev. Bras. Zootec. 37: 1953-1958. 
Cavalcante-Neto A, Lui JF, Sarmento JLR, Ribeiro MN, et al. (2008b). Efeitos genéticos e ambientais sobre a idade à primeira concepção de fêmeas suínas. Arq. Bras. Med. Vet. Zootec. 60: 499-502.

Cavalcante-Neto A, Lui JF, Sarmento JLR, Ribeiro MN, et al. (2009a). Estimation models of variance components for farrowing interval in swine. Braz. Arch. Biol. Technol. 52: 69-76.

Cavalcante-Neto A, Lui JF, Sarmento JLR, Ribeiro MN, et al. (2009b). Efeitos genéticos e não-genéticos sobre o intervalo de parto em fêmeas suínas no Sudeste do Brasil. Arq. Bras. Med. Vet. Zootec. 61: 280-285.

Cavalcante-Neto A, Tholon P, Lui JF, Lara MPC, et al. (2011). Random regression models with different residual variance structures for describing litter size in swine. Rev. Cienc. Agron. 42: 1043-1050.

Cesar AS, Silveira AC, Freitas PF, Guimaraes EC, et al. (2010). Influence of Chinese breeds on pork quality of commercial pig lines. Genet. Mol. Res. 9: 727-733.

Day BN (1980). Parturition. In: Current Therapy in Theriogenology: Diagnosis, Treatment and Prevention of Reproductive Diseases in Animals (Morrow DA, ed.). WB Saunders Company, Philadelphia, 1064-1067.

First NL, Lohse JK and Nara BS (1982). The Endocrine Control of Parturition. In: Control of Pig Reproduction (Cole DJ and Foxcroft GR, eds.). Butterworth Scientific, London, 331.

Freitas RTF (1998). Situação Atual e Perspectiva do Melhoramento de Suínos. Congresso Nacional dos Estudantes de Zootecnia, Viçosa, 461-471.

Giné GAF (2002). Estimativas de Parâmetros Genéticos para Características de Carcaça em um Rebanho de Suínos Large White. Master's thesis, Universidade Federal de Lavras, Lavras.

Gomes da Silva LP, Cavalcante-Neto A, Ribeiro MN, Lui JF, et al. (2007). Influência de fatores ambientais sobre o tamanho da leitegada ao nascer e taxa de mortalidade à desmama de leitões no brejo paraibano. Cienc. Anim. Bras. 8: $1-6$.

Irgang R (1977). Determinação do Desempenho Reprodutivo de Fêmeas da Raça Large White, Puras de Origem, Registradas no Pig Book Brasileiro. In: Suínos: Primeira Coletânea de Seminários. Empresa Brasileira de Pesquisa Agropecuária - EMBRAPA, Concórdia, 167-182.

Irgang R (1985). Estimativas de Herdabilidade para Características que Compõem a Produtividade Anual de Leitões por Porca. EMBRAPA-CNPSA, Concórdia.

Irgang R, Scheid IR and Fávero JA (1990). Aumento do Peso e Redução da Idade à Puberdade de Leitoas Através dos Cruzamentos. EMBRAPA-CNPSA, Concórdia.

Leite CDS, Lui JF, Albuquerque LG and Alves DNM (2011). Environmental and genetic factors affecting the weaning-estrus interval in sows. Genet. Mol. Res. 10: 2692-2701.

Médici KC, Barry AF, Alfieri AF and Alfieri AA (2010). VP6 gene diversity in Brazilian strains of porcine group C rotavirus. Genet. Mol. Res. 9: 506-513.

Mellagi APG, Vargas AJ, Furtado CSD, Amaral Filha WS, et al (2005). A Duração da Gestação de Suínos é Influenciada pelo Tamanho da Leitegada? XII Congresso Brasileiro de Veterinários Especialistas em Suínos, Fortaleza, 244-245.

Mrode RA (1996). Linear Models for the Prediction of Animal Breeding Values. Guildford: CAB International, Guildford.

Omtvedt IT, Stranislaw CM and Whatley JA Jr (1965). Relationship of gestation length, age and weight at breeding, and gestation gain to sow productivity at farrowing. J. Anim. Sci. 24: 531-535.

Pinheiro MJP, Galvão RJD, Bezerra Neto F and Espíndola GB (2000). Características reprodutivas de suínos puros na região semi-árida do Rio Grande do Norte. I. Tamanho da Leitegada. Caatinga 13: 19-26.

Prefeitura Municipal de Monte Alto (2006). Available at [http://www.montealto.sp.gov.br]. Accessed May 20, 2011.

Roehe R and Kennedy BW (1995). Estimation of genetic parameters for litter size in Canadian Yorkshire and Landrace swine with each parity of farrowing treated as a different trait. J. Anim. Sci. 73: 2959-2970.

Silveira AC, Braga TF, Almeida JF, Antunes RC, et al. (2009). PIT1 gene polymorphism in Pietrain and Large White pigs after divergent selection. Genet. Mol. Res. 8: 1008-1012.

Statistical Analysis System - SAS (1999). SAS/STAT: User's Guide, Version 9.1. Cary.

Torres Filho RA, Torres RA, Lopes PS, Euclydes RF, et al. (2004). Avaliação de modelos para estimação de componentes de (co)variância em características de desempenho e reprodutivas em suínos. Rev. Bras. Zootec. 33: 350-357.

Torres Filho RA, Torres RA, Lopes PS, Pereira CS, et al. (2005). Estimativas de parâmetros genéticos para características reprodutivas de suínos. Arq. Bras. Med. Vet. Zootec. 57: 684-689.

Upnmoor I (2000). Produção de Suínos: da Concepção ao Desmame. Agropecuária, Guaíba. 